\title{
The Possible Protective Role of Bone Marrow Transplantation against Alternations Induced by Gamma Radiations on Heart of Pregnant Albino Rats and Their Fetuses
}

\author{
Nahed Mohamed. Mansour Emam \\ Biological and Geological Dept., Faculty of Education \\ Suez Canal University, Ismailia, Egypt \\ Tel: 966-543-619-797 E- mail: mansour.nahed@yahoo.com
}

Mona Abel Rahman Ibrahim

Zoology Dept., Faculty of Science

Helwan University., Egypt

Tel: 966-508-205-5263Ｅ- mail: alaa2182@yahoo.com

Hend Abdel Karem Mohammed

Zoology Dept., Faculty of Science

Ain Shams University, Egypt

Tel: 966-562-098-686_E- mail: hakm376@yahoo.com

Received: December 1, 2012 Accepted: December 192012

doi:10.5296/jbls.v4i1.3245 URL: http://dx.doi.org/10.5296/jbls.v4i1.3245

\begin{abstract}
Aim of the work: It is well recognized that radiation can be carcinogenic. Bone marrow cells (BM) suppress immune cell responses and have beneficial effects in various inflammatory-related immune disorders. The present study is designed to evaluate the
\end{abstract}


possible role of bone marrow to restore certain histopathological and histochemical changes in the cardiac tissues of pregnant rats which exposed to gamma rays.

Material and Methods: The experimental animals were divided into five groups:

1- Group of control pregnant rats.

2- Group I\&II of pregnant rats irradiated with $\gamma$-rays on days 7 or 14 of gestation.

4- Group III\& IV of pregnant rats irradiated with $\gamma$-rays on day 7 or 14 of gestation and treated with BM one hour post-exposure. All the previous groups were sacrificed on day 20 of gestation (1 day prior delivery).

Results: Exposure of pregnant rats to $\gamma$-rays on day 7 or day 14 of gestation showed many pathological and histochemical changes in the cardiac tissues. These changes were more pronounced on day 14 of gestation. Bone marrow transplantation post-irradiation improved cardiac muscle architecture. On the other hand, fetal cardiac tissue was more sensitive to $\gamma$-rays than those of their mothers especially on day 14 of gestation. Bone marrow transplantation post-irradiation improved the tissue architecture which restored its normal histological and histochemical pictures.

Conclusion: It can be concluded that bone marrow transplantation post-irradiation showed somewhat a considerable ability to overcome radiation injuries or damages from the histological and histochemical point of view on day 7 or 14 of gestation.

Keywords: Heart- $\gamma$-rays, Pregnant rats, Fetuses, Bone marrow transplantation.

\section{Introduction}

The effects induced by ionizing radiation during embryonic development and fetal growth are a very important subject. Mammalian embryos were more sensitive to ionizing radiation than adults. Several authors showed that radiation induced abnormalities in mammals are closely related to the period of development of which radiation was given (Sharma and Saini, 2003; Maganha et al., 2006).

De Santis et al. (2005) suggested that ionizing radiation represented a possible teratogen for the fetus, but this risk has been found to be dependent on the dosage and the effects correlatable to the gestation age at exposure.

In addition, gamma radiation stimulates acute phase response. This response is essential for generation and limitation of inflammation. Individual acute phase reactants have different biochemical functions and hence regulatory mechanisms that are differentially observed within hours or days (Campbell et al., 2005).

Ramadan (2007a) detected a significant decrease in fetal numbers with numerous emberyonic malformations in irradiated pregnant rats with gamma rays at a dose of $0.5 \mathrm{~Gy}$ for 4 times on gestational days 9, 10, 11 and 12 . 
Qiu et al. 2011 concluded that exposure to electromagnetic waves altered the expression levels of tight junction proteins in the organs of adult male rats, which may induce changes in barrier structure and function.

Moreover, clear histopathological changes were observed after the whole body $\gamma$-irradiation in cardiac muscles. Abnormal structures of cardiac muscles were found as ill-defined shape, necrotic, pyknotic nuclei, sever dilated, widened and inflammated capillaries in endomysium ( Azab et al. 2011).

According to Pradeep et al. (2012), $\gamma$-radiation-induced cellular damage in the heart liver, and kidney of rats. Whole-body $\gamma$-radiation exposure $(5 \mathrm{~Gy})$ of healthy adult rats resulted in cellular damage and oxidative stress manifested as increased levels of serum marker enzymes, lipid peroxidation, and fibrosis in the tissues, accompanied by depletion of cellular glutathione and abnormal alteration in the levels of lysosomal enzymes. Moreover, the histological examination of Periodic acid-Schiff-stained tissue sections of animals following radiation exposure showed intensive necrotic damage.

Generally in the irradiated rats at two doses of 2 and 4Gy from cesium-137 source, a marked decrease in hepatic contents of DNA, and glutathione. The level of cholesterol, triglyceride, low density lipoprotein, alkaline phosphatase and gamma-glutamyl transferase were significantly increased in sera of the irradiated rats. This was coupled with a decreased serum level of high-density lipoprotein and total serum protein by irradiation (Makhlouf and Makhlouf 2012).

Stem cells are self-renewal and give rise to all differentiated cell types of the adult body. They are classified as toti-, pluri- or multi-potent stem cells based on the number of different cell types they can give rise to. Recently it has become apparent that chromatin regulation plays a critical role in determining the fate of stem cells and their descendants (Sang et al., 2009). Stem cell response can be influenced by the multitude of chemical, topological, mechanical and physiochemical factors (Tay et al., 2010).

In the treatment of chronic ischemic cardiomyopathy, MSCs were injected into acute myocardial infarction regions. MSCs in enhanced the contractile force of the cardiac muscle cells, regulated the contents and composition of collagen fibers in the tissue, and prevented the reconstruction of cardiac ventricles by protecting the basic structure of cardiac muscle (Chen $e t$ al., 2006).

Kafafy et al .(2006) mentioned that exposure of pregnant rats to 3Gy $\gamma$-rays on day 7 and day 13 of gestation followed by BMT one hour post-irradiation showed insignificant decrease in RBCs and hemoglobin but not in WBCs as compared to the control group.

Hou et al. (2007) stated that bone marrow-derived mesenchymal stem cells are of great therapeutic potential after myocardial ischemic injury. Transplantation of mesenchymal stem cells from human bone marrow improves damaged heart function in rats. Also, bone marrow-derived mononuclear cell transplantation improves myocardial recovery by enhancing cellular recruitment and differentiation at the infarction site (Makela et al.2007). 
Iyer and Rojas (2008) found that mesenchymal stem cells attenuated a self-inflammatory reaction and enhanced the anti-inflammatory reaction by regulating the proliferation, differentiation, and delomorphous nature of immunocytes. Mesenchymal stem cells (MSCs) are multipotent stem cells and had strong immunoregulatory effects.

Bone marrow transplantation after total body irradiation in mice demonstrated normal blood cell counts in $75 \%$ of recipients (Moroz et al ., 2009).

MSCs also played a special role in inhibiting inflammatory reactions and promoting tissue repair (Hanson et al., 2010; Tu et al. , 2012). Yagi et al. (2010) demonstrates that transplantation of bone marrow mesenchymal stromal cells can attenuate the effects of systemic inflammation and organ injury in two different animal models of injury. This therapeutic effect was observed in all three vital organs (liver, kidney and lung) in animals demonstrating the anti-inflammatory and anti-apoptotic effects of MSCs.

According to Bakhit (2010), BMT post-irradiation showed a marked ability to overcome radiation injuries or damages from the biochemical, biological, histological and histochemical point of view on day 7 of gestation in both maternal and fetal tissues, with less extent on day 14 of gestation.

Cell based therapy has been shown to attenuate myocardial dysfunction after myocardial infarction in different acute and chronic animal models. Intra myocardial injection of lentiviral infected endothelial progenitor cells (EPCs) is associated with a significant improvement of myocardial function after infarction, in contrast to an intracoronary application. Histological results revealed a significant augmentation of neovascularization, lower collagen content, higher numbers of inflammatory cells and remarkable alterations of apoptotic/proliferative processes in infracted areas after cell transplantation. Schuh et al (2012).

The present study has been involved to investigate the possible protective role of bone marrow transplantation from radiation hazards on heart tissue in pregnant rats and their fetuses.

\section{Material and Methods}

\subsection{Experimental Animals and Mating}

Mature male and virgin female albino rats of pure strain (Rattus albinus) ranging from 120-150 gm body weight were used in this experiment. Rats were obtained from the animal house belonging to the National Center for Radiation Research and Technology "NCRRT", Atomic Energy Authority, Egypt.

Animals were housed in especially designed cages, six females per cage. The males were kept separated from females until mating. All rats were kept under normal conditions. Females of proestrus and estrus periods were placed with fertile males at the ratio 2:1.Next morning, pregnancy was assured by the presence of vaginal plug that persists for 18-24 hours after which it falls. In the absence of vaginal plug, a drop from vaginal contents was prepared and examined under the microscope for the presence of spermatozoa. The presence of spermatozoa 
in smears confirmed that mating had taken place and that day was taken as the first day of pregnancy (Eda et al., 2009).

\subsection{Radiation Source}

Irradiation was performed by Gamma cell-40 (Cesium 137) located at the National Center for Radiation Research and Technology "NCRRT", Atomic Energy Authority, Cairo, Egypt. The Gamma - cell 40 (Cesium 137) irradiation unit manufactured by using the Atomic Energy of Canada Limit.

The dose rate of the Cesium 137 unit was 0.48 Gray / min at the time of the experimentation.

Pregnant rats were whole body irradiated at a single dose of $2 \mathrm{~Gy}$ gamma rays in the $7^{\text {th }}$ or $14^{\text {th }}$ day of gestation and sacrificed on day 20 of gestation (1 day prior delivery).

\subsection{Bone Marrow Transplantation}

Donors and recipients were chosen from the inbred strain. Sisters to sisters (isologous or syngenic transplantation). The donors were sacrificed by cervical dislocation.

Femur bones were dissected out, cleaned and both ends were chipped by bone nibbling forceps. Then the marrow was blown of the femur into saline solution under sterilized conditions by compressed air from a $10 \mathrm{ml}$ syringe fitted at one end of the shaft (Ashry et al., 2009).

The bone marrow was collected into sterile containers surrounded by ice cubes, and mixed by drawing and expelling it several times from the syringe without needle in order to avoid mechanical damage to the cells.

\subsection{Groups of animals}

Five groups of pregnant rats were used in the present experiment. Each group consisted of 6 animals

\section{The animals were divided into the following groups:}

A normal untreated control pregnant rats. The rats were sacrificed on day 20 of gestation.

A group of pregnant female rats exposed to 2 gray of gamma rays on day 7 of gestation (late implantation and early organogenesis) and sacrificed on day 20 of gestation $\left(\mathrm{R}_{7}\right)$.

A group of pregnant female rats exposed to 2 gray of gamma rays on day 7 of gestation and received bone marrow transplantation $(\mathrm{BMT}) 75 \times 10^{6} \pm 5$ cells by intraperitoneal injection one hour post-irradiation and sacrificed on day 20 of gestation $\left(\mathrm{R}_{7+\mathrm{BM}}\right)$.

A group of pregnant female rats exposed to 2 Gray of gamma rays on day 14 of gestation (organogenesis) and sacrificed on day 20 of gestation $\left(\mathrm{R}_{14}\right)$.

A group of pregnant female rats exposed to $2 \mathrm{~Gy}$ of gamma rays on day 14 of gestation and treated with bone marrow transplantation (BMT) one hour post- irradiation and sacrificed on day 20 of gestation $\left(\mathrm{R}_{14+\mathrm{BM}}\right)$.

\section{The Histological and histochemical studies:}


Following pregnant rats sacrifice, hearts from fetal and maternal rats were quickly removed and samples from the cardiac tissues were excised from the ventricle of each one and fixed in $10 \%$ neutral buffer formol and Carnoy's fluid for the histological and histochemical studies. Specimens were washed and dehydrated in ascending grades of alcohol, cleared in xylene and embedded in paraffin wax.

Sections were then cut at $5 \mu$ thickness and stained by haematoxylin and eosin stain according to the method of Drury and Wallington (1980), Periodic acid Schiff technique for demonstrating polysaccharides in the heart (Pearse, 1977). Mercuric bromophenol blue method for detecting total protein (Mazia et al., 1953). Mallory's trichrome stain for demonstrating collagen fibers (Pearse, 1977).

Image analysis: The optical density (pexil) of total protein and PAS+ve materials were analyzed by using image Pro. Program, Version 4.50

\section{Results}

\section{A-Histopathological observations of pregnant rats}

Heart of control mother.

The cardiac muscles of control mother rat revealed the common characteristics of normal cardiac muscle fibers each is surrounded by an endomysium of delicate connective tissue with rich capillary network (Fig. 1 a).

Heart of treated mothers.

Mother heart of irradiated pregnant rats (group R7) showed many changes including highly widened endomysium and degenerated muscle fibers with loss of striations with bizarre distribution of nuclei (Fig.1 b).

While the maternal heart of a pregnant rat exposed to gamma rays on 7 day of gestation and received bone marrow transplantation (group $\mathrm{R} 7+\mathrm{MB}$ ) showing disappearance of normal architecture of cardiac muscle fibers and most of their nuclei are irregularly distributed and faintly stained (Fig. $1 \mathrm{c}$ ). Also some lymphocytes were noticed in the endomysium.

Higher degree of histopathological changes was observed in group R14 in addition to highly dilated and elongated wall of the cardiac vein and arteries with disturbed arrangement of nuclei of tunica media with highly widened tunica adventitia (Figs. $1 \mathrm{~d} ; 1 \mathrm{e}$ ). The endomysium became wider than that of the previous groups, which may indicate a considerable degree of cardiac infarction (Fig. 1 f). Also highly degenerated areas and numerous pyknotic nuclei were detected (Fig. $1 \mathrm{f}$ )

These previous alternations were restored by bone marrow transplantation in group (R14+BM) and the cardiac muscles showed obvious return to normal myocardial appearance (Fig. $1 \mathrm{~g}$ ).

The alternations induced in connective tissues of cardiac muscles were investigated by Mallory's tripple technique. Control sections of muscle fibers revealed well organized collagen fibers which exhibited normal distribution of collagen fibers in and around the endomysium 


\section{Mll Macrothink}

between the muscle fibers (Fig. 2 a).

Increased collagen fibers were recorded in most of the collagen fibers of cardiac muscle tissues especially at R7, R14 groups (Figs.2 b, 2 d) when compared with similar places in control sections.

No changes were recorded in most of the collagen fibers of cardiac muscle tissues and exhibit somewhat normal distribution of collagen fibers in the endomysium at R7+BM, R14+BM groups (Figs.10, 12). However, brightly stained RBCs (Fig. 2 b), amorphous red stained parts of some muscle fibers as well as separation of muscle fibers (Fig. $2 \mathrm{~d}$ ) were also noticed.

Figure ( 3 a) showing normal PAS distribution in the maternal cardiac tissue of the control group. Reduced stain affinity of PAS +ve materials was detected in the maternal cardiac tissue of all treated groups (R7, R7+BM, R14, R14+BM) when compared with control group (Figs. 3 $\mathrm{b}-3 \mathrm{e})$. The MOD (mean optical density) values reached (1.34 \pm 0.20$),(1.38 \pm 0.08),(1.42 \pm 0.18)$ and (1.39 \pm 015$)$ in $\mathrm{R} 7, \mathrm{R} 7+\mathrm{BM}, \mathrm{R} 14, \mathrm{R} 14+\mathrm{BM}$ respectively compared with the control group $(1.56 \pm 0.07)$ as shown in histogram 1 .

Normal distribution of total proteins in the maternal cardiac tissue of the control group was observed in figure. (4a). The cardiac tissue of all treated groups (R7and R14) showed an increase in stain affinity of total proteins (Figs $4 \mathrm{~b} ; 4 \mathrm{~d}$ ). While, the total proteins in the maternal cardiac tissue in groups $(\mathrm{R} 7+\mathrm{BM}$ and $\mathrm{R} 14+\mathrm{BM})$ showed more or less normal appearance (Figs $4 \mathrm{c} ; 4$ e).

The MOD (mean optical density) values reached (1.49 \pm 0.11$),(1.26 \pm 0.09),(1.39 \pm 0.12)$ and (1.33 \pm 0.13$)$ in $\mathrm{R} 7, \mathrm{R} 7+\mathrm{BM}, \mathrm{R} 14, \mathrm{R} 14+\mathrm{BM}$ respectively compared with the control group (1.35 \pm 0.07 ) as shown in histogram 2 .

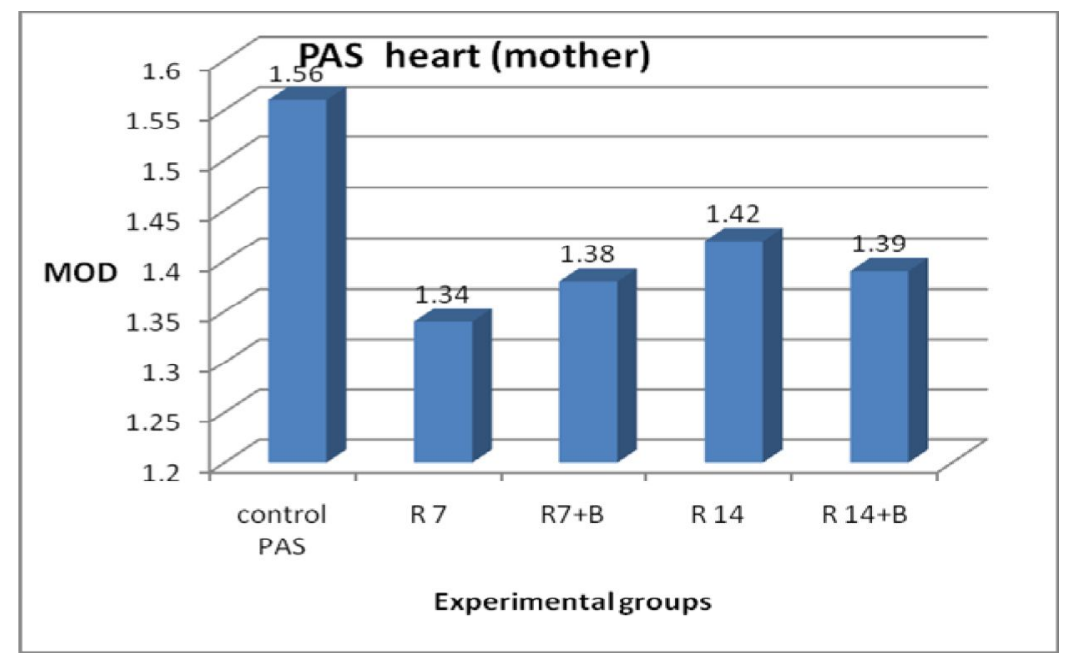

Histogram 1. Revealing MOD values of PAS +ve materials in heart (mother) of the control and treated groups. 


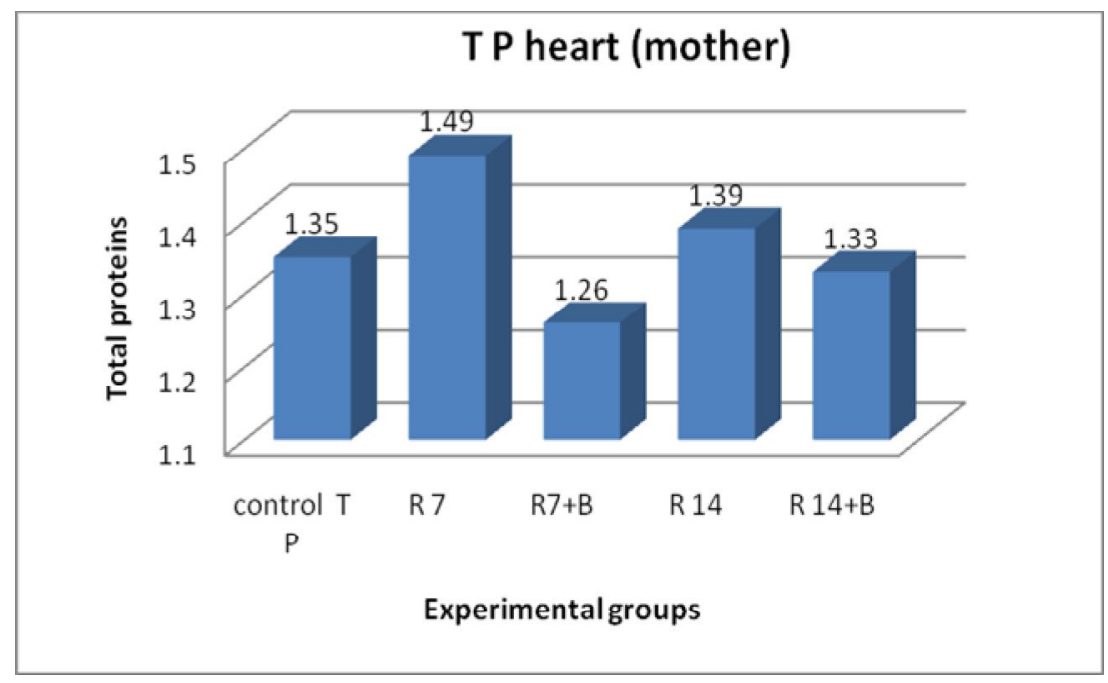

Histogram 2. Revealing MOD values of total proteins in heart (mother) of the control and treated groups.

\section{Histopathological observations of embryo}

Heart of control embryo

Normal appearance of cardiac tissues could be observed in Figure (5 a). In this figure, the longitudinal section of cardiac muscle illustrating variable diameter of the fibers and the central position of their nuclei.

Heart of treated embryos.

The fetal cardiac muscle tissue maternally irradiated with gamma rays on 7 day of gestation (R7group) showed numerous hemorrhagic areas, some degenerated areas (Fig. 5 b). Also the cytoplasm and the nuclei of cardiac muscle fibers appeared faintly stained.

The fetal cardiac muscle tissue maternally irradiated with gamma rays on 7 day of gestation and received bone marrow transplantation ( $\mathrm{R} 7+\mathrm{BM}$ group) showed somewhat normal appearance of cardiac muscle fibers but some hemorrhagic areas were still detected (Fig. 5 c).

Highly degenerated areas were observed in group R14 (Fig. 5 d). Most cardiac muscle fibers appeared with faintly stained cytoplasm and nuclei as shown in the same figure.

Figure (5e) illustrated somewhat normal appearance of cardiac muscle fibers or incomplete healing myocardium of fetal maternally irradiated with gamma rays on 14 day of gestation and received bone marrow transplantation (R14+BM group) although numerous widened endomysium were still detected.

Control sections of muscle fibers revealed well organized collagen fibers which exhibited normal distribution of collagen fibers in and around the endomysium between the muscle fibers (Fig. 6a).

Increased collagen fibers were recorded in most of the collagen fibers of cardiac muscle tissues 
especially at R7, R14 groups (Figs. 6 b; 6 d) when compared with control sections. Also numerous degenerated areas and red brightly stained RBCs were also detected in the same previous figures.

No changes were recorded in most of the collagen fibers of cardiac muscle tissues and exhibit somewhat normal distribution of collagen fibers in the endomysium at R7+BM, R14+BM groups (Figs. 6 c; 6 e). But numerous scattered small hemorrhagic areas contained red brightly stained RBCs were also noticed in the same previous figures.

Figure (7 a) showing normal PAS distribution in the fetal cardiac tissue of the control group. Increased stain affinity of PAS +ve materials was detected in the cardiac tissue of all treated groups (R7, R7+BM, R14, R14+BM) when compared with control group (Figs.7 b - 7 e).

The MOD (mean optical density) values reached $(1.65 \pm 0.13),(1.57 \pm 0.12),(2.00 \pm 0.20)$ and $(1.70 \pm 0.16)$ in $\mathrm{R} 7, \mathrm{R} 7+\mathrm{BM}, \mathrm{R} 14, \mathrm{R} 14+\mathrm{BM}$ respectively compared with the control group $(1.36 \pm 0.09)$ as shown in histogram 3 .

Normal distribution of total proteins in the fetal cardiac tissue of the control group was observed in figure. ( 8 a). the cardiac muscle tissues of group (R7) showed loss of stainability of total proteins (Fig. 8 b) when compared with control group but blood cells were deeply stained. The cardiac tissue of all other treated groups (R7+BM, R14, R14+BM) showed less increased in stain affinity of total proteins (Figs. $8 \mathrm{c}-8 \mathrm{e}$ ).

The MOD (mean optical density) values reached (1.12 \pm 0.13$),(1.22 \pm 0.08),(1.31 \pm 0.09)$ and $(1.41 \pm 0.11)$ in $\mathrm{R} 7, \mathrm{R} 7+\mathrm{BM}, \mathrm{R} 14, \mathrm{R} 14+\mathrm{BM}$ respectively compared with the control group $(1.20 \pm 0.09)$ as shown in histogram 4 .

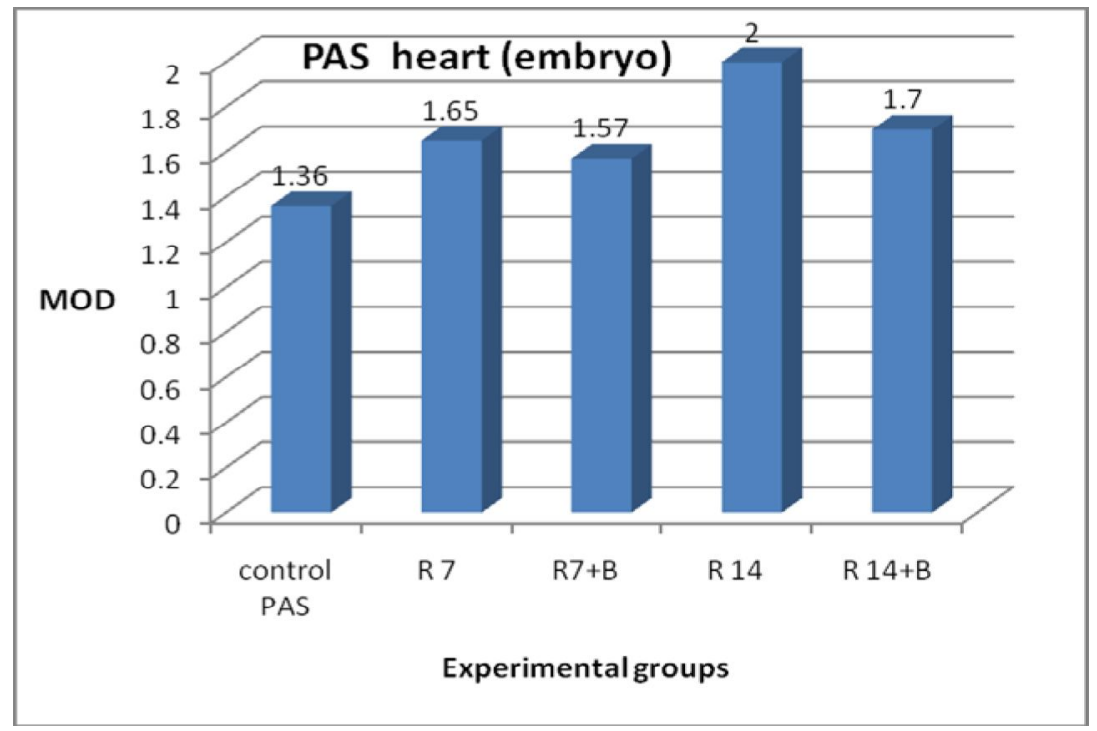

Histogram 3. Revealing MOD values of PAS +ve materials in heart (embryo) of the control and treated groups. 


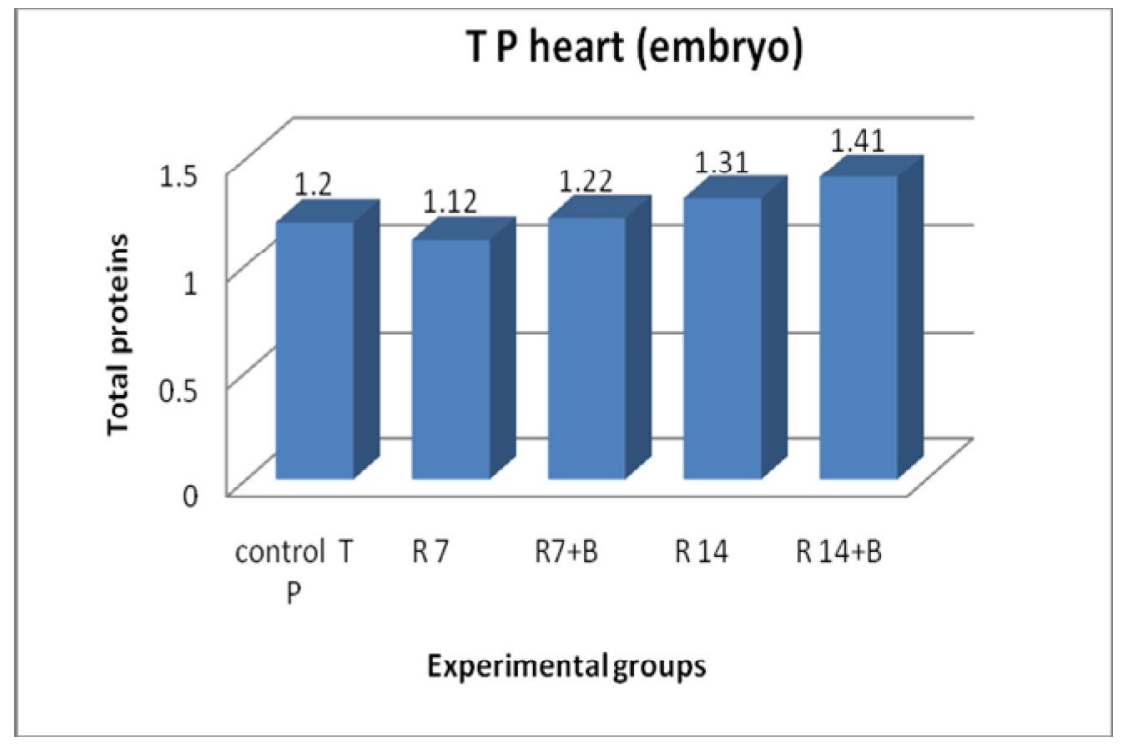

Histogram 4. Revealing MOD values of total proteins in heart (embryo) of the control and treated groups.

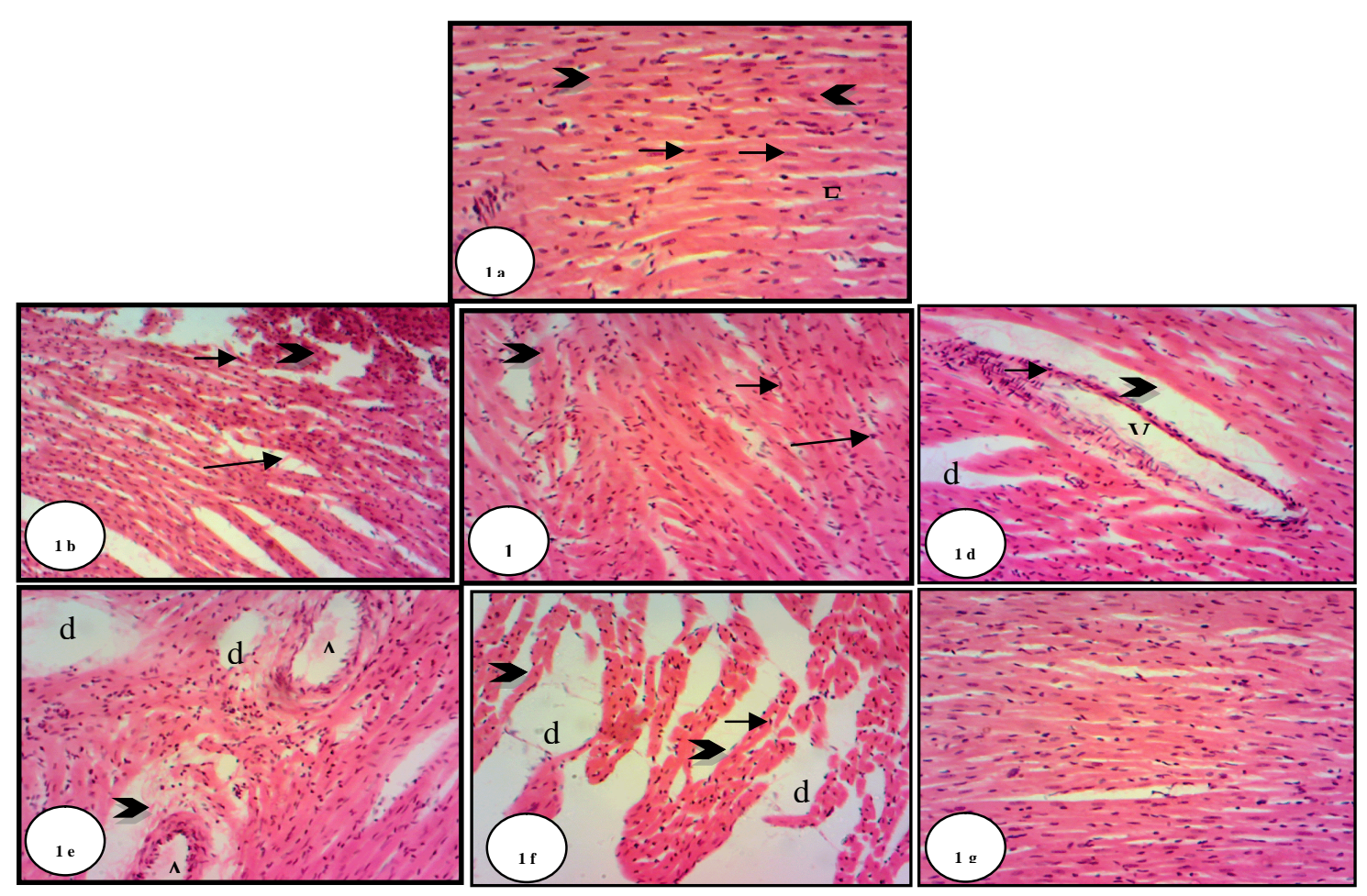

Fig. (1 a): A photograph of control mother cardiac muscle showing parallel and branched fibers (F) with centrally located nuclei (arrows). Arrow heads indicate striation of cardiac muscle fibers (H \& E; X 100).

Fig.(1 b): longitudinal section in the maternal cardiac muscle tissue of a pregnant rat exposed to 


\section{Ml Macrothink}

Journal of Biology and Life Science ISSN 2157-6076 2013, Vol. 4, No. 1

gamma rays on 7 day of gestation showing highly widened endomysium (long arrow), degenerated muscle fibers with loss of striations (arrow head), with bizarre distribution of nuclei (short arrow). (H \& E; X 100).

Fig.(1 c): Section in the maternal heart of a pregnant rat exposed to gamma rays on 7 day of gestation and received bone marrow transplantation showing disappearance of normal architecture of cardiac muscle fibers and most of their nuclei are irregularly distributed and faintly stained (short arrow). Note appearance of some lymphocytes (long arrow) in the endomysium d: degenerated muscle fibers (H \& E; X 100).

Fig.(1 d; 1 e ): Heart sections of a pregnant rat exposed to gamma rays on 14 day of gestation showing highly dilated and elongated wall of the cardiac vein (V) and arteries (A) with disturbed arrangement of nuclei of tunica media (arrows) with highly widened tunica adventitia (arrow heads). Note some degenerated areas (d) in the cardiac tissue. (H \& E; X 100).

Fig. (1 f): Another section of the myocardium of a pregnant rat exposed to gamma rays on 14 day of gestation showing atrophied muscle fibers with dilated endomysium (arrow heads). Note highly degenerated areas (d), numerous pyknotic nuclei (arrow). (H \& E ; X 100).

Fig.(1 g): A photograph of cardiac muscle tissue of a pregnant rat exposed to gamma rays on day 14 of gestation and received bone marrow transplantation showing obvious return to normal myocardial appearance. (H \& E; X 100).
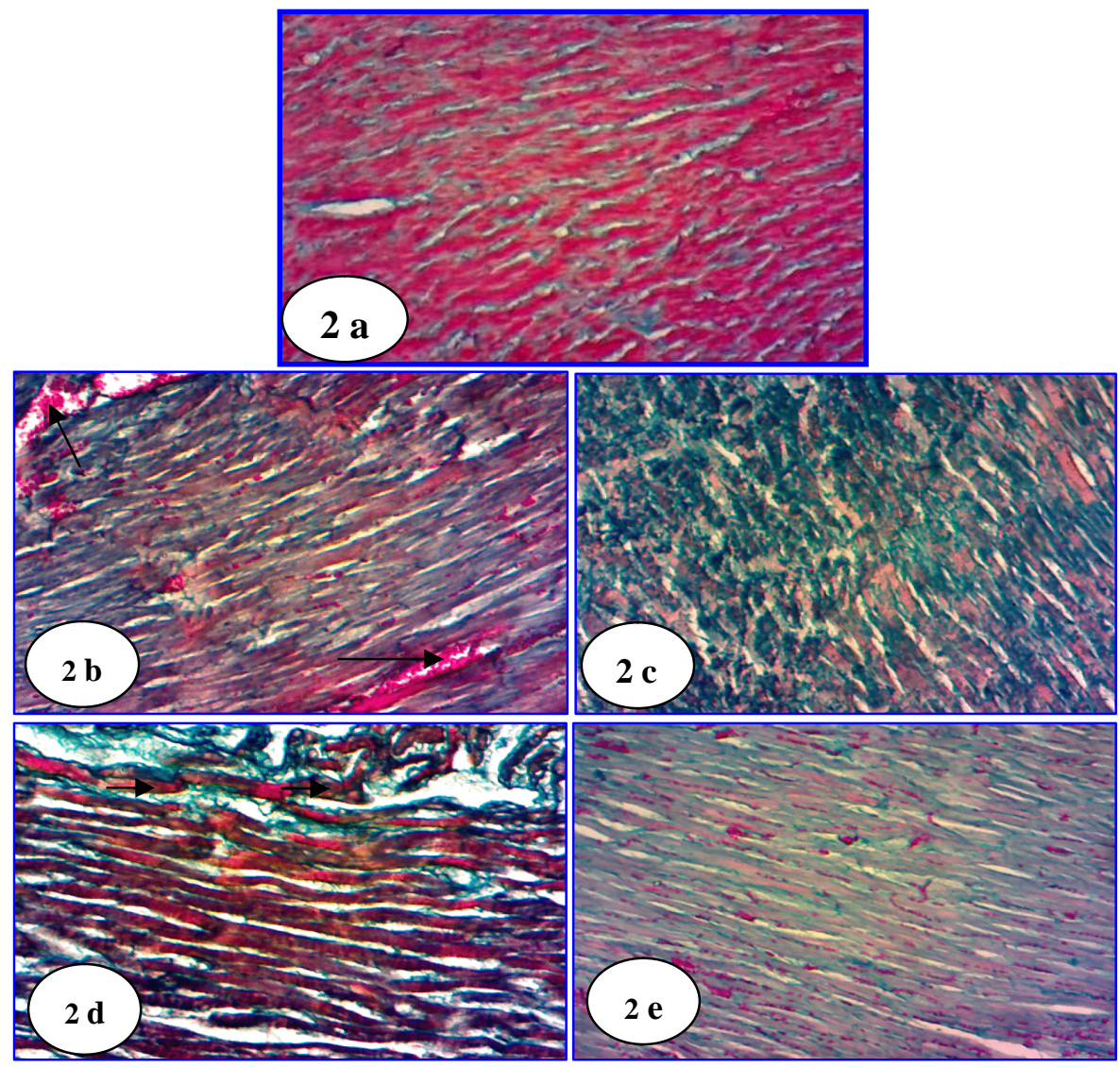


\section{MInstitute Macrothink $_{\text {Ins }}$}

Journal of Biology and Life Science

ISSN 2157-6076

2013, Vol. 4, No. 1

Fig.(2 a): A photograph of control maternal cardiac muscle showing normal distribution of collagen fibers in and around the endomysium between the muscle fibers. (Mallory's trichorome stain X 100)

Fig.(2 b): A photograph showing increased collagen fibers in and around the endomysium of a cardiac muscle fibers of a pregnant rat irradiated with gamma rays on 7 day of gestation. Note brightly stained RBCs (arrows). (Mallory's trichorome stain X 100)

Fig.(2 c): A photograph of maternal cardiac muscle of a pregnant rat irradiated with gamma rays on 7 day of gestation and received bone marrow transplantation showing somewhat increased collagen fibers in and around the endomysium between the muscle fibers. (Mallory's trichorome stain X 100)

Fig.(2 d): A photograph showing highly increased collagen fibers in and around the highly widened endomysium of a cardiac muscle fibers of a pregnant rat irradiated with gamma rays on 14 day of gestation. Note highly separated muscle fibers (arrows). (Mallory's trichorome stain X 100)

Fig.(2 e): A photograph of maternal cardiac muscle of a pregnant rat irradiated with gamma rays on 14 day of gestation and received bone marrow transplantation showing somewhat normal distribution of collagen fibers. (Mallory's trichorome stain X 100)

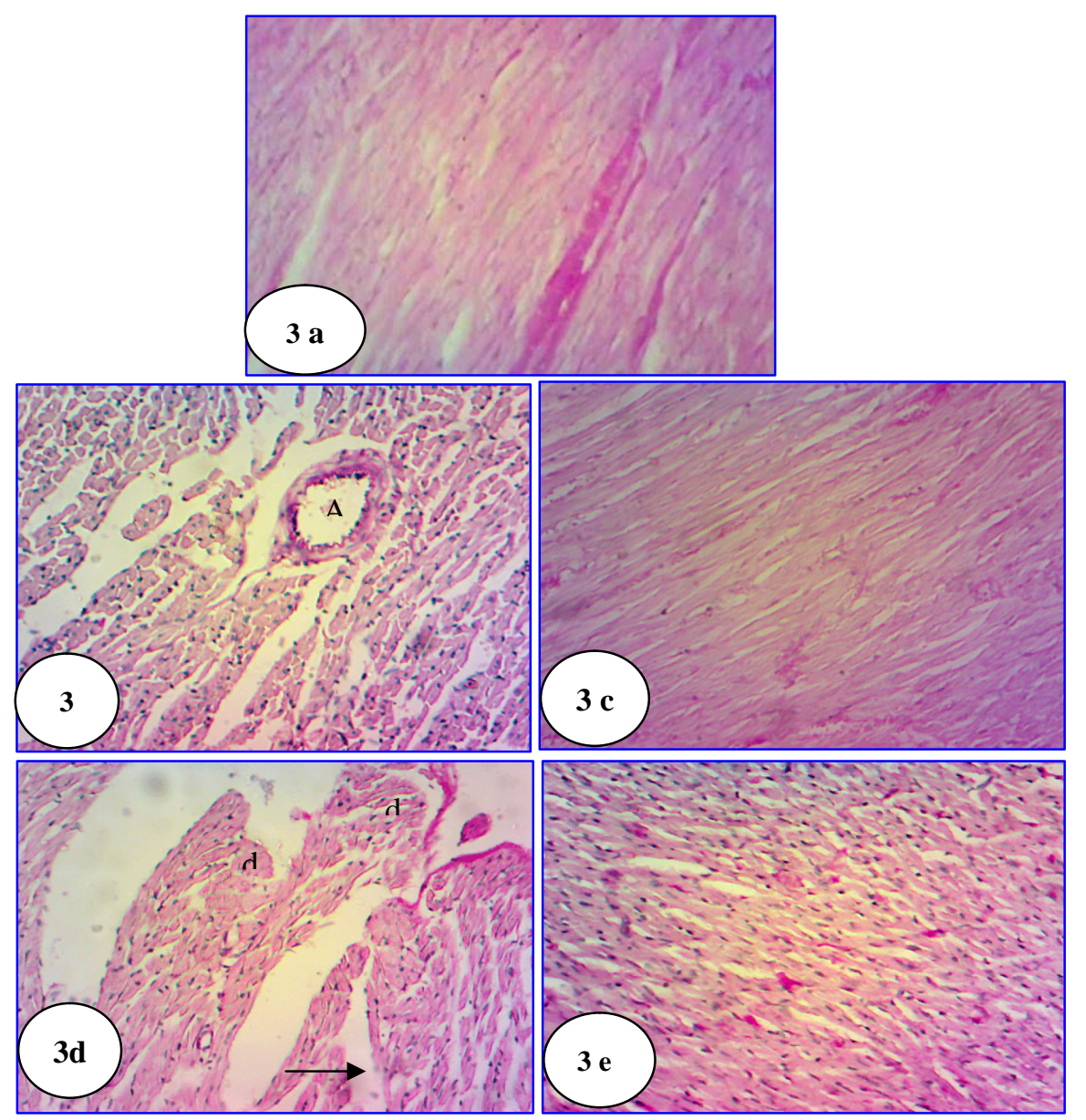




\section{$\triangle$ Macrothink}

Journal of Biology and Life Science ISSN 2157-6076 2013, Vol. 4, No. 1

Fig.(3 a): A photograph showing normal PAS distribution in the maternal cardiac tissue of the rol group. (PAS X 100).

Fig.(3 b): A photograph showing highly decreased_PAS distribution in the maternal cardiac tissue of a pregnant rat irradiated with gamma rays on 7 day of gestation. Note degenerated muscle fibers, highly dilated wall of the cardiac artery (A). (PAS X 100).

Fig. (3 c): A photograph showing also decreased PAS distribution in the maternal cardiac tissue of of a pregnant rat irradiated with gamma rays on 7 day of gestation and received bone marrow transplantation. (PAS X 100).

Fig.(3 d): A photograph showing decreased PAS distribution in the maternal cardiac tissue of a pregnant rat irradiated with gamma rays on 14 day of gestation. Note highly degenerated muscle fibers (d), highly widened endomysium (arrow). (PAS X 100).

Fig.(3 e): A photograph showing decreased PAS distribution in the maternal cardiac tissue of a pregnant rat irradiated with gamma rays on 14 day of gestation and received bone marrow transplantation (PAS X 100).

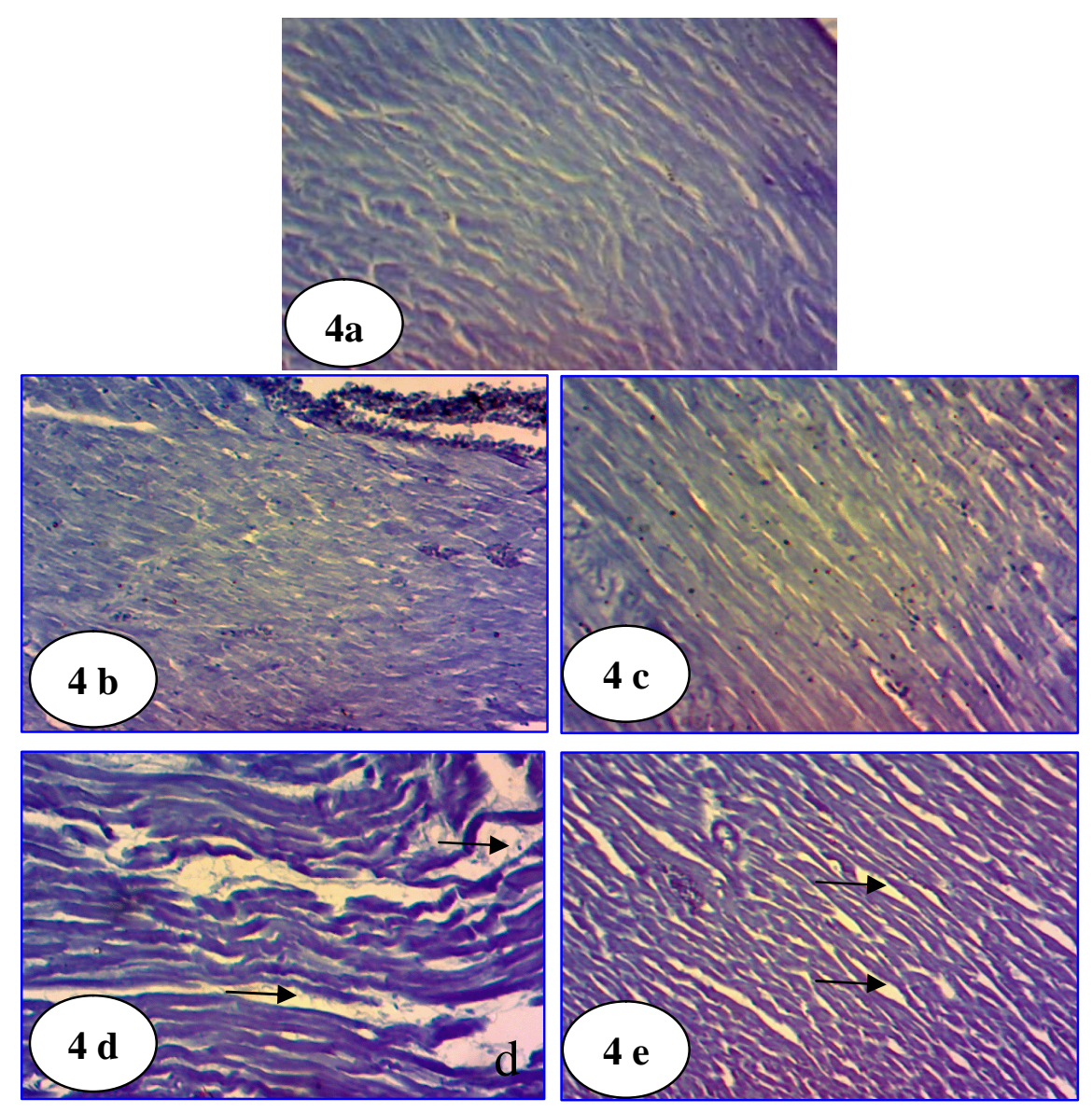

Fig.(4 a): A photograph showing normal distribution of total proteins in the maternal cardiac tissue of the control group. Mercuric bromophenol blue X 100).

Fig.(4 b): A photograph showing increased total protein distribution in the maternal cardiac 


\section{MInstitute Macrothink $_{\text {Int }}$}

Journal of Biology and Life Science

ISSN 2157-6076

2013, Vol. 4, No. 1

tissue of a pregnant rat irradiated with gamma rays on 7 day of gestation. (Mercuric bromophenol blue X 100).

Fig.(4 c): A photograph showing nearly normal total protein distribution in the maternal cardiac tissue of of a pregnant rat irradiated with gamma rays on 7 day of gestation and received bone marrow transplantation. (Mercuric bromophenol blue X 100).

Fig.(4 d): A photograph showing increased total protein distribution in the maternal cardiac tissue of a pregnant rat irradiated with gamma rays on 14 day of gestation. Note highly degenerated muscle fibers (d), highly dilated endomysium (arrows). (Mercuric bromophenol blue X 100).

Fig.(4 e): A photograph showing somewhat normal total protein distribution in the maternal cardiac tissue of a pregnant rat irradiated with gamma rays on 14 day of gestation and received bone marrow transplantation. Note widened endomysium (arrows). ercuric bromophenol blue X 100).

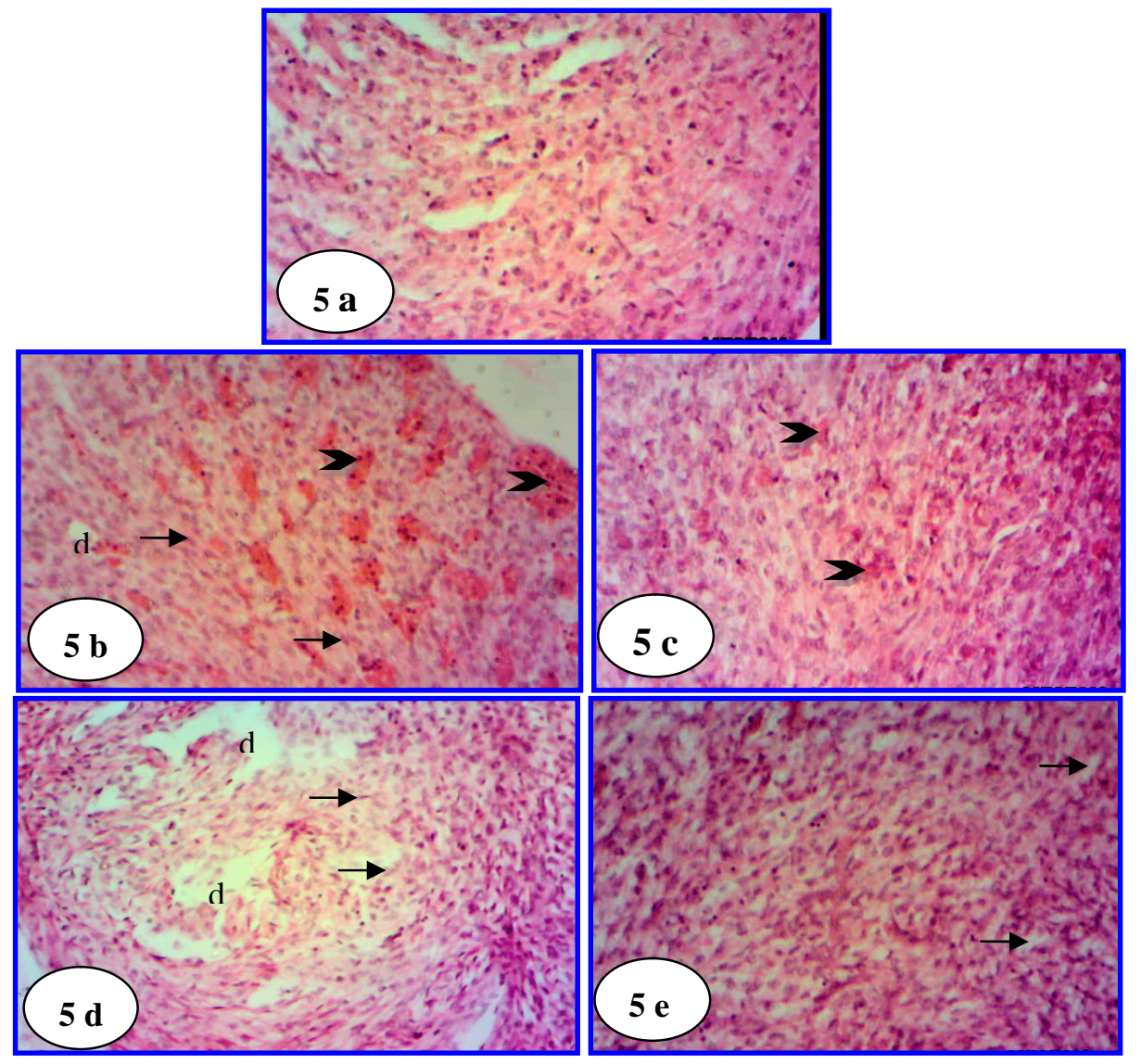

Fig.(5 a): A photograph of cardiac muscle fibers of untreated control fetal group showing normal architecture of the myocardium. (H \& E; X 100).

Fig.(5 b): Section of fetal cardiac muscle tissue maternally irradiated with gamma rays on 7 day of gestation showing numerous hemorrhagic areas (arrow heads), some degenerated areas (d). Note the cytoplasm and the nuclei of cardiac muscle fibers are faintly stained (arrows).

Fig.(5 c): Section of fetal cardiac muscle tissue maternally irradiated with gamma rays on 7 day 


\section{MInstitute ${ }_{\text {Int }}^{\text {Macrothink }}$}

Journal of Biology and Life Science ISSN 2157-6076 2013, Vol. 4, No. 1

of gestation and received bone marrow transplantation showing somewhat normal appearance of cardiac muscle fibers but some hemorrhagic areas were still detected (arrows). (H \& E; X 100).

Fig.(5 d): A photograph of fetal cardiac muscle tissue maternally irradiated with gamma rays on 14 day of gestation showing highly degenerated areas (d). Note most cardiac muscle fibers appeared with faintly stained cytoplasm and nuclei (arrows). (H \& E ; X 100).

Fig.(5 e): A photograph showing incompletely healing myocardium of fetal maternally irradiated with gamma rays on 14 day of gestation and received bone marrow transplantation . Note some normal appearance of cardiac muscle fibers but numerous widened endomysium (arrows) were still detected. (H \& E ; X 100).
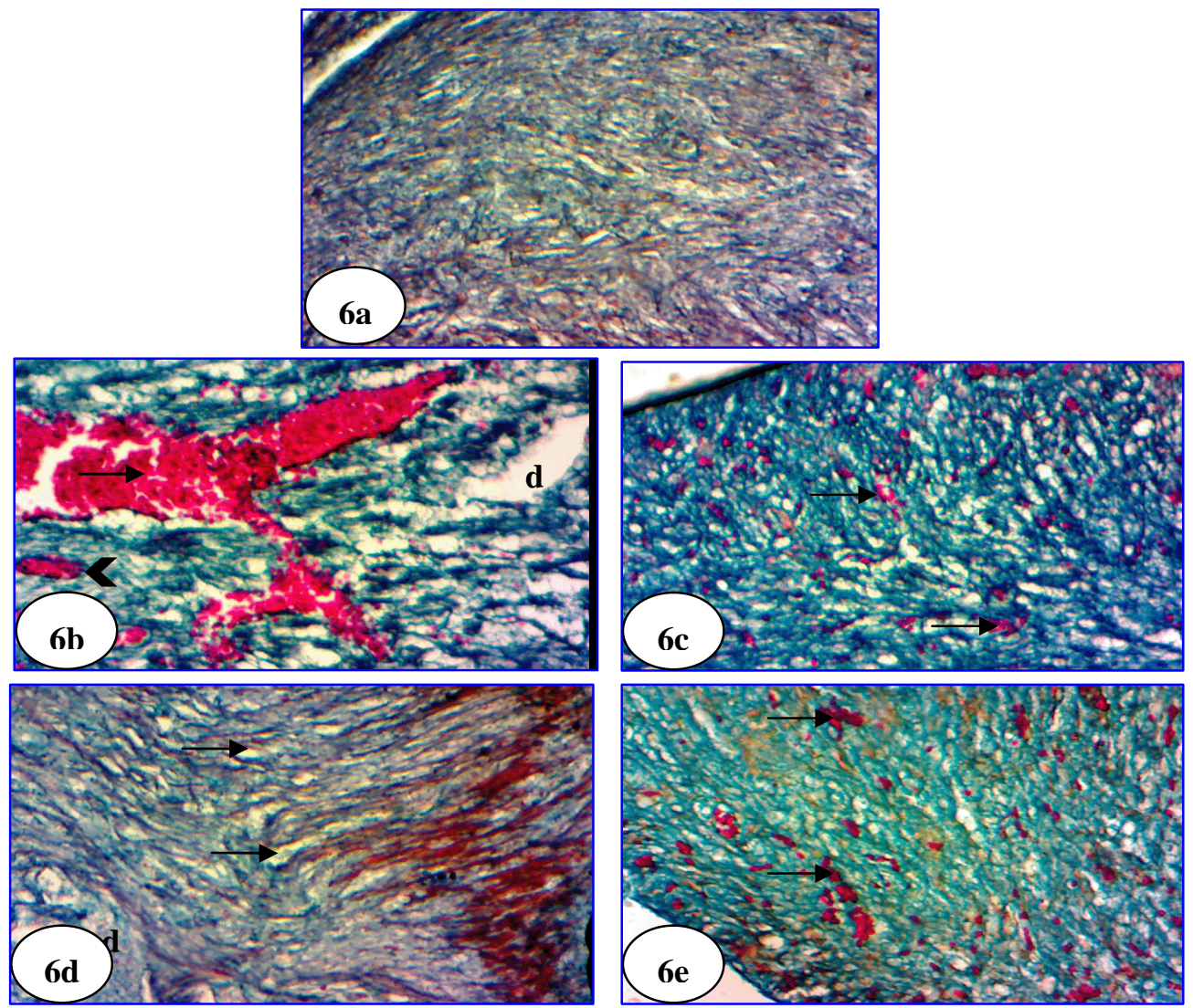

Fig. (6 a): A photograph showing normal distribution of collagen fibers in the control fetal cardiac tissues. (Mallory's trichorome stain X 100)

Fig.(6 b): A photograph of fetal cardiac muscle tissue maternally irradiated with gamma rays on 7 day of gestation showing negatively degenerated areas (d), increased stain affinity of collagen fibers of some other areas . Notice: red brightly stained RBCs (arrow) in the branched, dilated and elongated blood vessel and inside the congested endomysium (arrow head). (Mallory's trichorome stain X 100).

Fig.(6 c): Section of fetal cardiac muscle tissue maternally irradiated with gamma rays on 7 day of gestation and received bone marrow transplantation showing somewhat normal appearance 


\section{Ml Macrothink}

of collagen fibers but scattered small hemorrhagic areas contained red brightly stained RBCs (arrows). (Mallory's trichorome stain X 100).

Fig.(6 d): A photograph of fetal cardiac muscle tissue maternally irradiated with gamma rays on 14 day of gestation showing increased collagen fibers of in and around cardiac muscle fiber and inside the widened endomysium (arrows). $d$ : degenerated areas (Mallory's trichorome stain X 100).

Fig.(6 e): Section of fetal cardiac muscle tissue maternally irradiated with gamma rays on 14 day of gestation and received bone marrow transplantation showing somewhat normal distribution of collagen fibers. But numerous scattered small hemorrhagic areas were still detected, contained red brightly stained RBCs (arrows). (Mallory's trichorome stain X 100).

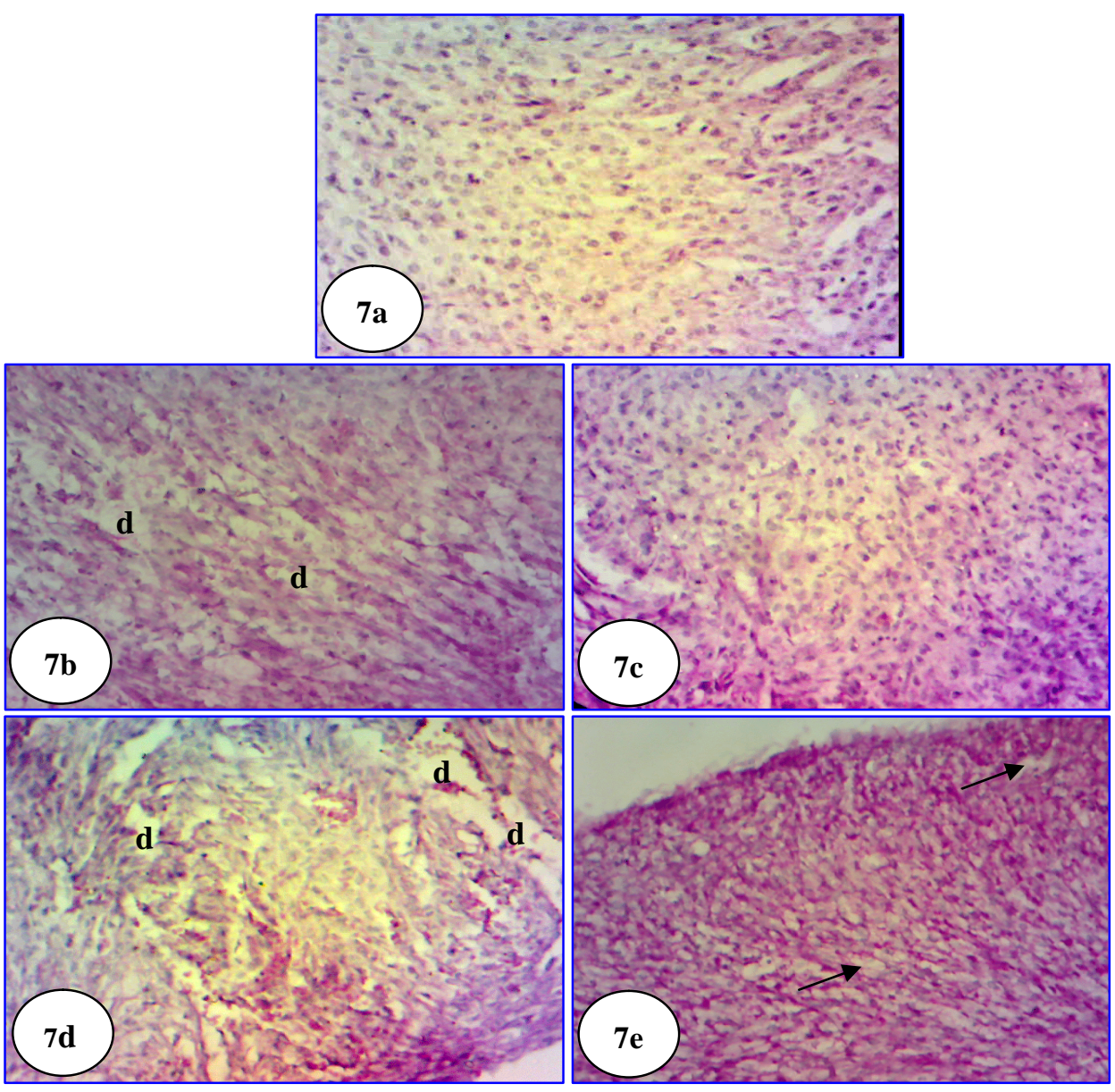

Fig.(7 a): A photograph showing normal distribution of PAS +ve materials in the control fetal myocardium. (PAS X 100).

Fig.(7 b):A photograph of fetal cardiac muscle tissue maternally irradiated with gamma rays on 7 day of gestation showing negatively degenerated areas (d), increased stain affinity PAS +ve materials in some other areas. (PAS X 100).

Fig.(7 c): A photograph showing also increased PAS distribution in the fetal cardiac tissue maternally irradiated with gamma rays on 7 day of gestation and received bone marrow 
transplantation. (PAS X 100).

Fig. (7 d): A photograph showing highly increased PAS distribution in the fetal cardiac tissue maternally irradiated with gamma rays on 14 day of gestation. Note highly degenerated areas (d) were negatively stained. (PAS X 100).

Fig.(7 e): A photograph showing also increased PAS distribution in the fetal cardiac tissue maternally irradiated with gamma rays on 7 day of gestation and received bone marrow transplantation. Note widened endomysium were poorly stained (arrows). (PAS X 100).
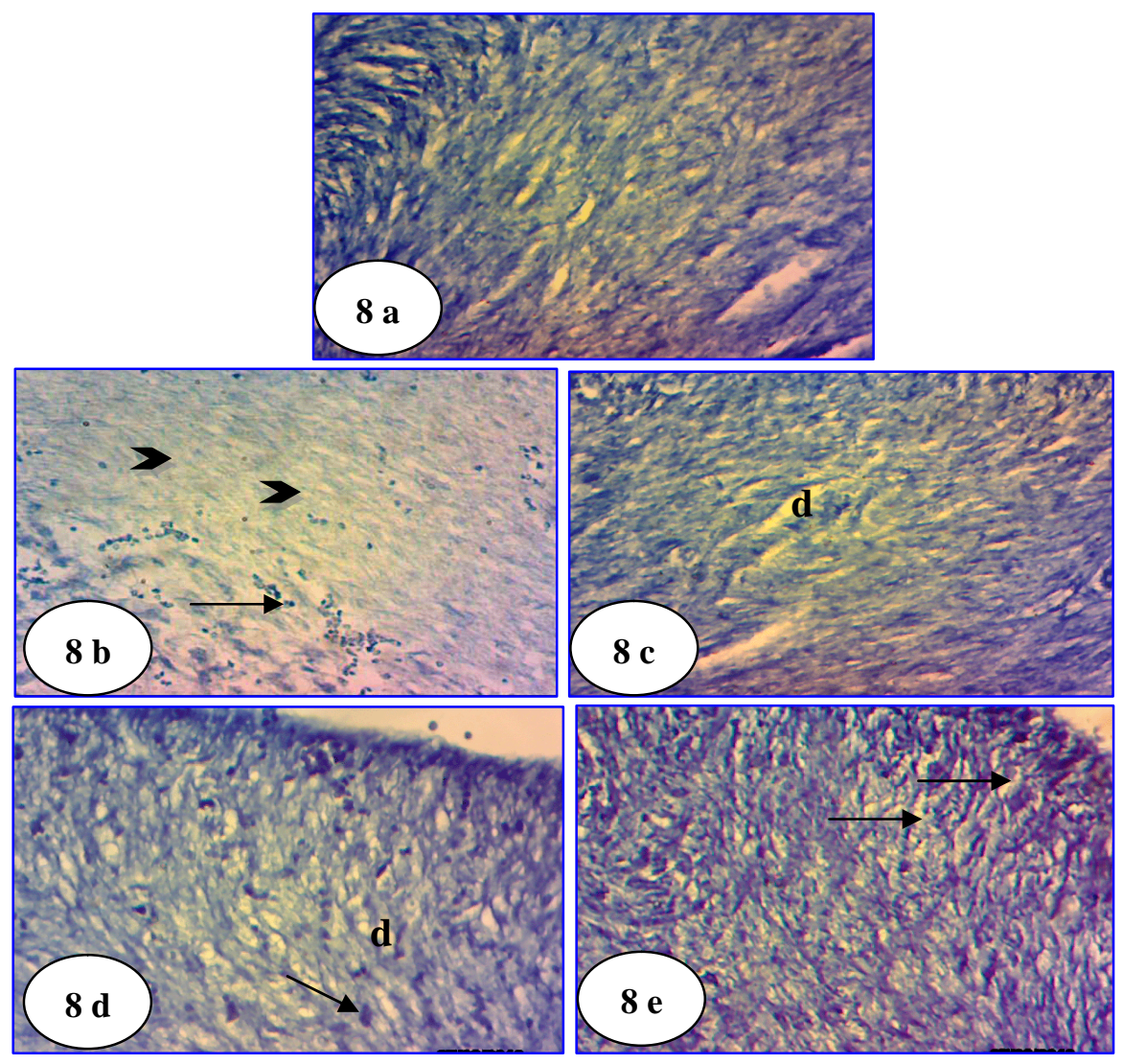

Fig.(8 a): A photograph showing normal distribution of total protein in the fetal cardiac tissues from control group. (Mercuric bromophenol blue X 100).

Fig.(8 b): A photograph showing decreased distribution of total protein of fetal cardiac muscle tissue maternally irradiated with gamma rays on 7 day of gestation. Note faintly stain cardiac muscle fibers (arrow heads) but blood cells were deeply stained (arrow). (Mercuric bromophenol blue X 100).

Fig.(8 c): A photograph showing somewhat incomplete healing with less increased total protein distribution in the fetal cardiac tissue maternally irradiated with gamma rays on 7 day of gestation and received bone marrow transplantation. Note some degenerated areas were negatively stained (d). (Mercuric bromophenol blue X 100).

Fig.(8 d): A photograph showing increased total protein distribution in the fetal cardiac tissue 
maternally irradiated with gamma rays on 14 day of gestation. Note highly numerous degenerated areas (d) were negatively or faintly stained and blood cells were deeply stained (arrow). (Mercuric bromophenol blue X 100).

Fig.(8 e): A photograph showing also increased total protein distribution in the fetal cardiac tissue maternally irradiated with gamma rays on 14 day of gestation and received bone marrow transplantation. But numerous widened endomysium were negatively stained (arrows). (Mercuric bromophenol blue X 100).

\section{Discussion}

Humans on earth are exposed to many sources of ionizing radiation. The largest component of man-made background radiation relates to exposures associated with medical diagnosis and treatments. Clinical and pathological studies revealed that radiation therapy can produce significant tissue injury (Malik et al. 2010). On the other hand, bone marrow cells suppress immune cell responses and have beneficial effects in various inflammatory-related immune disorders (Yagi et al. 2010). Therapeutic studies for bone marrow transplantation for treatment of radiation injuries and its consequences are not more available. Thus, this work investigates the role of bone marrow transplantation against alternations induced by Gamma radiations on cardiac tissues of pregnant rats and their fetuses .

Exposure to $\gamma$-rays during different periods of gestation induced significant developmental toxicity in pregnant female rats and their fetuses. This developmental toxicity included increased resorption and reduced fetal weight (Ramadan, 2007b).

In the present study heart of the pregnant rats exposed to $2 \mathrm{~Gy}$ of $\gamma$-rays on day 7 or day 14 of gestation showed many drastic changes in the cardiac tissue. These changes were more pronounced on day 14 of gestation. In accordance with Pradeep et al. (2012), whole-body $\gamma$-radiation exposure ( $5 \mathrm{~Gy}$ ) of healthy adult rats resulted in cellular damage in the heart, liver, and kidney tissues of rats.

Dilatation of blood vessels were observed post-irradiation with lymphocytic infiltration between the degenerated areas. These results were also recorded by several authors (Ali and Haggag, 2006; Abdel Mottaal and Abdel Maguid, 2007, Bakhit, 2010 ; Azab et al. 2011).

Highly widened endomysium and degenerated areas in the cardiac tissue observed in the present study could be considered as a reactive change that may be related to the inhibitory effect on the vascular smooth muscles which induced relaxation and consequent vasodilatation (Melamed et al ., 2003). This vasodilatation and increased vascular permeability should lead to loss of fluid from the blood, so the vessels are engorged with blood cells with consequent slowing down of the blood stream which would result in degeneration and necrosis in the cardiac tissues.

In the present study bone marrow transplantation improved the heart architecture in pregnant rats exposed to $2 \mathrm{~Gy}$ on day 7 or 14 of gestation, but, this improvement was more obvious on day 14 of gestation. On day 7 of gestation some degenerated areas were still noticed.

Signs of improvement in many tissues of pregnant rats exposed to different doses of gamma 
rays and treated with bone marrow were detected by many authors (Hussein, 2004; Hasan, 2007, Bakhit, 2010 ).

The histological damage might result from an increase in the process of lipid peroxidation and a decrease in the activity of antioxidant enzymes of the body with the consequent damage of cellular membranes (El-Habit et al., 2000; Saada and Azab, 2001).

In the present study highly increased collagen fibers were detected in heart tissue of the pregnant rats exposed to $2 \mathrm{~Gy}$ of $\gamma$-rays on day 7 or especially on day 14 of gestation.

Increased collagen post-irradiation exposure in the different tissues was detected by several authors (Eid and Al Dossary, 2007; El-Salkh, 2009).

George et al. (2001) suggested that decreased synthesis of collagenolytic enzymes might contribute to further accumulation of collagen.

In the present study, nearly moderate increase normal collagen content was noticed in the heart tissue of the pregnant rats exposed to $2 \mathrm{~Gy}$ of $\gamma$-rays on day 7 of gestation followed by bone marrow transplantation. Similar findings were observed by Bakhit (2010) on collagen fibers of hepatic tissues of the pregnant rats exposed to $2 \mathrm{~Gy}$ of $\gamma$-rays on day 14 of gestation followed by bone marrow transplantation.

In the present study radiation exposure showed decreased glycogen in the cardiac tissue of the pregnant rats exposed to $2 \mathrm{~Gy}$ of $\gamma$-rays on day 7 or day 14 of gestation. This is may be due to failure of the tissue to synthesize or store glycogen and may be also a result of degeneration observed in the endomysium. Decreased glycogen content post-irradiation exposure was noticed in studies of many authors (Abdel Mottaal and Abdel Maguid, 2007; Bakhit, 2010).

In the present study cardiac tissue of the pregnant rats exposed to radiation on days 7 or day 14 of gestation followed by BMT also showed decreased glycogen content. In contrast to Bakhit (2010) the level of glycogen content of hepatic tissue of the pregnant rats exposed to radiation on days 7 or day 14 of gestation followed by BMT restored to its normal level.

In the present study radiation exposure showed increased total proteins in the cardiac tissue of the pregnant rats exposed to $2 \mathrm{~Gy}$ of $\gamma$-rays on day 7 or day 14 of gestation. Increased total protein in tissues post exposure to different types of radiations was noticed by many authors (Al Dossary, 2007; El-Salkh, 2009). Highly affected protein and DNA post-irradiation exposure may be due to response of hydrogen bonds of these materials to radiation (Bakhit, 2010).

Bone marrow transplantation post-irradiation in this study showed more or less normal total protein content in the cardiac tissue of pregnant rats on day 7 or day 14 of gestation. Treatment with bone marrow post-irradiation exposure showed normal appearance of total protein content of the liver and lung tissues of pregnant rats exposed to $2 \mathrm{~Gy} \gamma$-rays on day 7 or 14 of gestation (Bakhit, 2010).

Also, Yagi et al. (2010) reported that histological analysis demonstrated a significant reduction of tissue injury with less apoptotic cells in bone marrow mesenchymal stromal cells treated 
animals compared to controls and the liver sections showed significantly less inflammatory cell infiltration compared to control animals.

Fetal cardiac tissues were more sensitive to $\gamma$-rays than those of their mothers especially on day 14 of gestation. This sensitivity was discussed by several authors (Oktem et al., 2005; Ittrich et al., 2007). In the present study fetal cardiac tissue showed many drastic changes include: numerous degenerated areas, many hemorrhagic areas and widened endomysium. The cytoplasm and the nuclei of cardiac muscle fibers appeared faintly stained.

In the present study bone marrow transplantation post-irradiation (2Gy) on day 7 or 14 of gestation caused moderate improvement in the architecture of the fetal cardiac tissue, in spite of presence of numerous widened endomysium and some hemorrhagic areas.

According to Abu Gabal et al. (1998) bone marrow transplantation post-exposure to pregnant mothers has shown to improve the developing fetus and it's placenta, being more effective with the lower radiation dose level.

Recently, bone marrow-derived cells have been shown to successfully accelerate burn wound healing and promote the recovery of ischemic heart failure (Yeo et al. , 2009)

The present results revealed that in case of injury, the stem cells from bone marrow are responsible for tissue regeneration and these cells have unique properties that make them attractive candidates for the treatment of diseases and injuries. Also stem cells can be transplanted to replace non-functional or lost stem cells in tissues to accelerate tissue healing and restore the original function (Burt et al., 2008).

The regenerative potential of stem cells was studied by several authors (Ferrari et al., 1998; Pye and Watt, 2001; Kirsch et al., 2010).

The improvement observed in the fetal lung tissue maternally exposed to $\gamma$-rays and treated with BM may be due to the ability of bone marrow cells to differentiate to mature, non-haematopoitic cells of multiple tissues (Abedi et al., 2004).

Results of the present study showed highly increased collagen fibers, red brightly stained RBCs in the fetal cardiac tissue maternally exposed to 2 Gy of $\gamma$-rays on day 7 or day 14 of gestation. These results are in accordance with those of Bakhit (2010) who showed highly increased collagen fibers, in the fetal liver and lung tissue maternally exposed to $2 \mathrm{~Gy}$ of $\gamma$-rays on day 7 or day 14 of gestation.

In accordance with Bakhit (2010) on other tissues, the present study fetal cardiac tissue taken from mothers exposed to $2 \mathrm{~Gy}$ of $\gamma$-rays on day 14 of gestation and treated with bone marrow showed somewhat normal content of collagen fibers.

Results of the present study showed increased or highly increased glycogen content in cytoplasm of the fetal cardiac tissue taken from mothers exposed to $2 \mathrm{~Gy}$ gamma rays on day7and day 14 of gestation. These results are in accordance with those of Moustafa and Hafez (1998) who noticed increased glycogen content in cytoplasm of the fetal liver tissue taken from mothers exposed to 2Gy gamma rays on day 11 of gestation. Also, Gorczynska and 
Wegrynowicz (1991) noticed increased glycogen content in the tissues post-irradiation. They stated that this increase may be due to increased cortisol which usually leads to an accumulation of glycogen in the tissue

In the present study fetal cardiac tissue maternally treated with $2 \mathrm{~Gy}$ of $\gamma$-rays on day 7 or day 14 of gestation followed by bone marrow restorted their highly increased content of glycogen but the less increased values were still detected.

In the present study increased stain affinity of total protein content was observed in the fetal heart tissue exposed maternally to $2 \mathrm{~Gy} \gamma$-rays on day 14 of gestation but faintly stained cardiac muscle fibers with deeply stained blood cells were detected on day 7 of gestation. This increase in stain affinity of total protein may be due to increased RBCs or may be due to appearance of the fibrous tissue, but, reduced stain affinity of total protein may be due to damaged protein molecules by irradiation. These results could be attributed to the destruction of cellular structure which causes activation and liberation of proteolytic enzymes followed by autodigestion of host tissue which induces inflammatory responses usually accompanied by changes in total serum proteins (Ali et al., 2007).

This decrease in total protein may be due to highly affected RER, mitochondria and Golgi apparatus with increased lysosomes noted by Eid and Al Dossary (2007) in fetal hepatocytes exposed maternally to EMF radiation. Also, decreased protein content was noted in hepatocytes post-irradiation by Al-Gahtani (2006).

Bone marrow treatment post-radiation exposure on day 7 or 14 of gestation nearly restored the total protein content in the fetal cardiac tissue to the somewhat less increased level, in spite of deeply stained RBCs inside the endomysium. Bakhit (2010) reported that nearly normal total protein content was detected in the fetal lung tissue maternally treated with the bone marrow post-irradiation on day 7 of gestation but on day 14 of gestation showed increased stain affinity of total protein.

The regenerative potential of stem cells was studied by several authors (Pye and Watt, 2001; Kirsch et al., 2010).

The improvement observed in the fetal tissues maternally exposed to $\gamma$-rays and treated with BM may be due to the ability of bone marrow cells to differentiate to mature, non-haematopoitic cells of multiple tissues (Abedi et al., 2004).

It is clear that pregnant rats and their fetuses which were exposed to $2 \mathrm{~Gy} \gamma$-rays on day 14 of gestation were more sensitive to $\gamma$-rays than those exposed on day 7 of gestation. Bone marrow transplantation cannot completely overcome radiation injury or restore the normal histological pattern and normal content of collagen, polysaccharides and total protein in the tissues exposed on day 14 of gestation.

\section{References}

Abdel Mottaal, N. \& Abdel Maguid, A.(2007). Effect of fractionated and single doses $\gamma$-irradiation on certain mammalian organs. Egypt .J. of Hospital Medicine, 19, 111-122. 
Abedi, M., Greer, D., Colvin, G., Demers, D., Dooner, M., Harpel, J., Pimental, J., Menon, M.\& Quesenberry, P. (2004). Tissue injury in marrow transdifferentiation. Sci. Direct., 32(1), 42-46.

Abu Gabal, H., Roushdy, H., Abu Sinna, G. \& Ashry, O. (1998). Control of in utero embryonic teratogenicity and placental tissue damage through isologous bone marrow transplantation to irradiated pregnant albino mice. J. Egypt. Ger. Soc. Zool., 25 (B), vertebrate Anatomy and Embryology, 113-137.

Al Dossary, A. (2007). Histological and histochemical response to low frequency electromagnetic field on liver, kidney and spleen of adult female's albino rats and their fetuses. M.Sc. Thesis, King Faisal Univ.K.S.A.

Al Gahtani, S. (2006). Histological and histochemical studies on the effect of two different types of magnetic field on the liver and kidney of albino rats. M.Sc. Zoology Department, Girls College of Science, Dammam, K.S.A.

Ali, H., Faddah, L., Rizk, M. \& El-Ebiary, H. (2007). Role of anserine and/or zinc in modulating nucleic acid and protein disorders in rats exposed to gamma irradiation. Journal of Pharmacology and Toxicology, 2, 1-19. http://dx.doi.org/10.3923/jpt.2007.1.19

Ali, S., \& Haggag, A. (2006). Reducing of radiation hazard by green Tea. Arab.J. Nucl. Sci. Appli., 39 (3): 288-297.

Ashry, O., Hussein, E, \& Salama, S. (2009). Boosting of antioxidant defense by interferon-alfa in irradiated bone marrow transplanted rats. Egypt. J. Rad, Sic. Applic., 22(1), 19-33.

Azab, K., Bashandy, M., Salem, M., Ahmed, O., Tawfi, Z. \& Helal, H. (2011). Royal jelly modulates oxidative stress and tissue injury in gamma irradiated male Wister Albino rats. North Am J Med Sci, 3, 268-276. http://dx.doi.org/10.4297/najms.2011.3268

Bakhit, M. (2010). Modulation of radiation injury in pregnant rats by bone marrow transplantation. M.Sc. Faculty of Science, Zoology Department, Al -Azhar University Cairo Egypt.

Burt, R., Loh, Y., \& Pearce, W. (2008). Clinical application of blood derived and marrow derived stem cells for nonmalignant diseases. J.A.M.A. 299(8), 935-936. http://dx.doi.org/10.1001/jama.299.8.925

Campbell, J., Prichard, L., Schmitz, J., Stephenson, F. \& Rosenfeld, M. (2005). Expression of suppressors of cytokines signaling during liver regeneration. J. Clin. Invest., 107, 1285-1292. http://dx.doi.org/10.1172/JCI11867

Chen, S., Liu, Z., Tian, N., Zhang, J., Yei, F., Duan, B., Zhu, Z., Lin, S. \& Kwan, T. (2008). Intracoronary transplantation of autologous bone marrow mesenchymal stem cells for ischemic cardiomyopathy due to isolated chronic occluded left anterior descending artery. $J$ Invasive Cardiol, 18, 552-556.

De Santis, M. D., Gianantonio, E., Straface, G., Cavaliere, A., Caruso, A., Schiavon, F., Berletti, R. \& Clementi, M. (2005). Ionizing radiation in pregnancy and teratogenesis A review of 
literature. Rep. Toxi., 20, 323-329. http://dx.doi.org/10.1016/j.reprotox.2005.04.004

Drury, R. \& Wallington, E. (1980). Carleton's Histological Technique. ( $4^{\text {th }}$ ed). Oxford. Univ. Press, New York, Toronto.

Eda, K., Buyuknacar, H., Gocmen, C., Evruke, I. \& Onder, S. (2009). Differential effect of neocuproine, a copper(I) chelator, on contractile activity in isolated ovariectomized non-pregnant rat, pregnant rat and pregnant human uterus. European Journal of Pharmacology, 605, 158-163. http://dx.doi.org/10.1016/j.ejphar.2009.01.008

Eid, F. \& Al Dossary, A. (2007): Ultrastructural, histological and histochemical studies on the effect of electraomagnetic field on the liver of pregnant rats and their fetuses. The Egypt. J. of Hospital Medicine, 28, 273-294.

El Salkh, B. (2009). Histological and histochemical studies on the effect of the alternating magnetic field on the mice lung. Egypt. J. Biomed. Sci., 29, 351-366.

El-Habit, O., Saada, H., Azab, K., Abdel Rahman, M. \& El Malah, D. (2000). The modifying effect of beta carotene on gamma radiation-induced elevation of oxidative reactions and genotoxicityin male rats. Mut. Res., 466, 179-190. http://dx.doi.org/10.1016/S1383-5718(00)00010-3

Ferrari, G., Cusella, G., Coletta, M., Paolucci, E., Stornaiuolo, A. \& Cossu, G. (1998).Muscle regeneration by bone marrow myogenic progenitors. Science, 279, 1528-1540. http://dx.doi.org/10.1126/science.279.5356.1528

George, I., Ramesh, k., Stem, R. \& Chandrakasan, G. (2001). Dimethyl nitrosamine-induced liver injury in rats: the early deposition of collagen. Toxicology, 156, 129-138. http://dx.doi.org/10.1016/S0300-483X(00)00352-8

Gorczynska, E., \& Wegrynowicz, R. (1991). Structural and functional changes in organelles of liver cells on rat exposed to magnetic fields. Environ. Res., 55, 188-189. http://dx.doi.org/10.1016/S0013-9351(05)80175-6

Hanson, S., Gutowski, K. ,\& Hematti uP (2010). Clinical applications of mesenchymal stem cells in soft tissue augmentation. Aesthet Surg. J., 30, 838-842.

Hasan, H. (2007). Biological studies of the effect of a venom fraction isolated from the scorpion, Androctonus amoreuxi on irradiated rats, M.Sc. Thesis, Faculty of Science Ain Shams Univ.

Hou, M., Yang, K., Zhang, H., Zhu, W., Duan, F., Wang, H., Song, Y., Wei, Y., \& Hu, A. (2007). Transplantation of mesenchymal stem cells from human bone marrow improves damaged heart function in rats. International Journal of Cardiology, 115(2), 220-228. http://dx.doi.org/10.1016/j.ijcard.2006.03.028

Hussein, E. (2004). Natural protection of bone marrow transplantation to gamma irradiated pregnant rats in view of better restoration of certain vital organ functions. Ph.D. Thesis, Faculty of Science, Ain Shams Univ.

Ittrich, H., Lange, C., Togel, F., Zander, A., Dahnke, H., Westenfelder, C., Adam, G., \& Nolte- 
Ernsting, C. (2007). In vivo magnetin response imaging of iron oxidelabeled, arteriallyinjected mesenchymal stem cells in kidneys of rats with acute ischemic kidney injury: Detection and monitoring at 3T. J. Magn. Reson. Imaging, 25(6), 1179-1191. http://dx.doi.org/10.1002/jmri.20925

Iyer, S., \& Rojas, M. (2008). Anti-inflammatory effects of mesenchymal stem cells: novel concept for future therapies. Expert. Opin. Biol. Ther., 8, 569-581. http://dx.doi.org/10.1517/14712598.8.5.569

Kafafy, Y., Roushdy, H., El Beih, H., \& Hussein, E. (2006). Propolis maintaining the restrorative role played by bone marrow transplantation in pregnant rats exposed to whole body gamma-irradiation. J. Rad. Sci. Appli., 19(2), 353-371.

Kirsch, D., Grimm, J., Guimaraes, A., Weissleder, R., \& Jacks, T. (2010). Imaging primary lung in mice to study radiation biology. Int. J. of Rad. Oncology "Biology" Physics, 76(4), 973-977.

Maganha, J., Souza, E., Marcos, R., Brando, A., Peters, V., \& Guerra, M. (2006).Development alternation in rats treated with lapachol. Braz. Arch. Bio. Technol., 49(6), 927-934. http://dx.doi.org/10.1590/S1516-89132006000700010

Makela, J., Ylitalo, K., Lehtonen, S., Dahlbacka, S., Niemelä, E., Kiviluoma, K., Rimpiläinen, J., Alaoja, H., Paavonen, T., Lehenkari, P., Juvonen, T., \& Anttila, V. (2007). Bone marrow-derived mononuclear cell transplantation improves myocardial recovery by enhancing cellular recruitment and differentiation at the infarction site, The Journal of Thoracic and Cardiovascular Surgery, 134(3), 565-573. http://dx.doi.org/10.1016/j.jtcvs.2007.05.004

Makhlouf, R., \& Makhlouf, I. (2012). Evaluation of the effect of Spirulina against Gamma irradiation induced oxidative stress and tissue injury in rats. Journal of Applied Sciences and Engineering Research, 1(2),153-164.

Malik, I., Moriconi, F., Sheikh, N., Naz, A., Khan, S., Dudas, J., Mansurogl, T., Hess, C., Friedrich. 1., Frank, M., Hans, H., \& Ramadori, G. (2010). Single-dose gamma-irradiation induces up-regulation of chemokine gene expression and recruitment of granulocytes into the portal area but not into other regions of rat hepatic tissue. The American Journal of Pathology; 176 (4), 1801-1814. http://dx.doi.org/10.2353/ajpath.2010.090505

Mazia, D., Brewer, P., \& Alfert, M. (1953). The cytochemical staining and measurement of protein with mercuric bromophenol blue. Biol. Bull., 104, 57-67. http://dx.doi.org/10.2307/1538691

Melamed, R., Bar-Yosef, S., Shakhar, G., Shakhar, K., \& Ben-Eliyahu, S. (2003). Suppression of natural killer cell activity and promotion of tumor metastasis by ketamine, thiopental, and halothane, but not by propofol:mediating mechanisms and prophylactic measure. Anesth. Analg., 97, 1331-1339. http://dx.doi.org/10.1213/01.ANE.0000082995.44040.07

Moroz, C., Traub, L., Rabizadeh, E., \& Zahalka, M. (2009). A proof of concept study: Human 
$\mathrm{C}^{48}$ placenta immunoregulatory factor is an effective, single therapeutic agent enabling allogeneic, nonmanipulated murine bone marrow transplantation. Exp. Hematol., 37, 1121-1130. http://dx.doi.org/10.1016/j.exphem.2009.06.002

Moustafa, N., \& Hafez, M. (1998). The possible protective effects of Nigella Sativa on mice fetuses of mothers exposed to $\gamma$-rays. Egypt. J. Histol., 21(2), 235-250.

Oktem, F., Ozguner, F., Mollaoglu, H., Koyu, A., \& Uz, E. (2005). Oxidative damage in the kidney induced by $900-\mathrm{MHz}$-emitted mobile Phone: Protection by melatonin. Arch. Med.Res., 36(4), 350-355. http://dx.doi.org/10.1016/j.arcmed.2005.03.021

Pearse, A. (1977): Histochemistry, Theoretical, and Applied. (3 ${ }^{\text {th }}$ ed.). vol.1. Churchill Livingstone, London.

Pradeep, K., Ko, K. , Choi, M ., Kang, J. , Chung, Y., \& Park, S .(2012). Protective effect of hesperidin, a citrus flavanoglycone, against $\gamma$-radiation-induced tissue damage in Sprague-Dawley rats. J Med Food. , 15(5),419-27. http://dx.doi.org/10.1089/jmf.2011.1737

Pye, S., \& Watt, D. (2001). Dermal fibroblast participate in the formation of new muscle fibers when implanted into regenerating normal mouse muscle. J. Anat., 198, 163-172. http://dx.doi.org/10.1046/j.1469-7580.2001.19820163.x

Qiu, L., Chen, C., Ding, G., Zhou, Y., \& Zhang, M. (2011). The effects of electromagnetic pulse on the protein levels of tight junction associated-proteins in the cerebral cortex, hippocampus, heart, lung, and testis of rats. Biomed. Environ .Sci., 24(4),438-444.

Ramadan, F. (2007a). Malformations induced by gamma irradiation combined with vitamin A administration in pregnant female albino rats and their fetuses. Egypt. J. Rad. Sci. Applic., 20(2), 475-496.

Ramadan, F. (2007b). Efficacy of wheat germ oil in alleviating certain disorders induced by aspirin administration and / or X-rays in pregnant albino rats and their fetuses. Egypt. J. Rad. Sci. Applic., 20(2), 497-520.

Saada, H., \& Azab, K. (2001). Role of lycopene in recovery of radiation induced injury to mammalian cellular organelles. J. Pharmazie , 56(3), 239-240.

Sang ,Y., Feng, W. M., \& Wagner, D. (2009). The stem cell chromatin connection. Seminars in cell \& Develomental Biology, 20(9), 1143-1148.

Schuh, A., Kroh, A., Konschalla, S., Liehn, E., Sobota, R., Biessen, E., Bot, I., Sonmez, Z., Schober, A., Marx, N., Weber, C., \& Sasse, A. (2012). Myocardial regeneration by transplantation of modified endothelial progenitor cells expressing SDF-1 in a rat model. Journal of Cellular and Molecular Medicine. In press. http://dx.doi.org/10.1111/j.1582-4934.2012.01539.x

Sharma, P., \& Saini, M. (2003). Modification of radiation induced mortality by cysteamine, MPG and their combination in Swiss albino mice. Ind. J. Nuc. Med., 18(1, 2), 12 - 18.

Tay, C., Yu, H., Pal, M. et al. (2010). Micropatterned matrix directs differentiation of human 


\section{Macrothink}

mesenchymal stem cells towards myocardial lineage. Experimental Cell Research, 316(7), 1159-1168. http://dx.doi.org/10.1016/j.yexcr.2010.02.010

Tu, X., Song, J., Xue, X., Guo, X., Ma, Y., Chen, Z., Zou, Z., \& Wang, L. (2012). Role of bone marrow-derived mesenchymal stem cells in a rat model of severe acute pancreatitis. World J. Gastroenterol., 18(18), 2270-2279. http://dx.doi.org/10.3748/wjg.v18.i18.2270

Yagi, H., Gutierrez, A., Kitagawa, Y., Tilles, W., Tompkins, R., \& Yarmush , M. (2010). Bone marrow mesenchymal stromal cells attenuate organ injury induced by LPS and Burn. Cell Transplant., 19(6), 823-830. http://dx.doi.org/10.3727/096368910X508942

Yeo, C., Mathur, A., \& Autologous, A. (2009). Bone marrow-derived stem cells for ischemic heart failure regenerate-IHD trial. Regenerative Medicine.,4(1),119-127. http://dx.doi.org/10.2217/17460751.4.1.119

\section{Copyright Disclaimer}

Copyright reserved by the author(s).

This article is an open-access article distributed under the terms and conditions of the Creative Commons Attribution license (http://creativecommons.org/licenses/by/3.0/). 